\title{
CURRENT STATE AND PROSPECTS OF CERTIFICATION OF CHERNIHIV REGION FOREST RESOURCES
}

\author{
O. Tertychna ${ }^{1}$, G. Ryabukha ${ }^{2}$, N. Miroshnyk ${ }^{3}$, K. Kudriashova ${ }^{2}$
}

${ }^{1}$ Інститут агроекології і природокористування НААН (м. Київ, Україна) e-mail: olyater@ukr.net; ORCID:0000-0002-9514-2858

${ }^{2}$ Національний університет «Чернігівська політехніка» (м. Чернігів, Україна) e-mail: g.ryabukha@gmail.com; ORCID: 0000-0003-2146-7489

e-mail: Katrinchernigov@gmail.com;ORCID: 0000-0002-5626-0958

3 ДУ «Інститут еволюційної екології НАН України» (м. Київ, Україна)

У статті досліджено значення лісогосподарського комплексу з екологічної точки зору для підтримання природної рівноваги та збереженні біорізноманіття, та з економічної - відповідності міжнародним стандартам та доступу до міжнародних ринків збуту. Проаналізовано площі, які вкриті лісовою рослинністю, а також лісистість територій європейських держав та України. Виявлено відхилення фактичної середньої лісистості території від оптимальної в Україні на 4,1\%. Розглянуті зональні показники лісистості України та ідентифіковані території країни з недостатнім залісненням. Розглянуто важливість лісової сертифікації для забезпечення економічно та екологічно збалансованого ведення лісового господарства. Аргументовано перспективність лісовоі сертифікації у підвищенні конкурентоспроможності, інвестиційної привабливості та інтеграції вітчизняних лісових господарств. Доведено взаємозалежність дотримання міжнародних вимог щодо ведення лісового господарства та можлливість доступу до екологічно чутливих ринків. Ідентифіковані основні завдання лісової сертифікаціі щодо виконання міжнародних зобов'язань ведення лісового господарства та лісокористування на засадах сталого розвитку. Статистично підтверджено збільшення площ сертифікованих лісів у світі та визначено пріоритетною для дослідження за показниками динаміки зростання FSC сертифікація. Наведені та охарактеризовані три види сертифікації: системи ведення лісового господарства, ланцюга постачання і контрольованої деревини. Проаналізовані відмінності між видами сертифікації та необхідність отримання для підприємств лісового господарства різного виробничого спрямування. Визначено типи лісової сертифікації (індивідуальна, групова, багатолокаційна) та наведено відмінності та особливості отримання. Аналітично підтверджено позитивну динаміку за площею сертифікованих лісів, темпами росту площі, темпами росту кількості сертифікатів ведення лісового господарства та сертифікатів ланцюга постачання українських виробників. Проаналізовано діяльність лісових господарств Чернігівської області упродовж 2015-2020 рр. за площею сертифікованих лісів, видами лісової рослинності та площами заліснення. Виокремлено діючі FSC сертифіковані держсавні підприємства Чернігівської області: ДП «Новгород-Сіверське лісове господарство», ДП «Ніжинське лісове господарство», ДП «Холминське лісове господарство», досліджено сертифіковані види продукції та виявлено перспективні напрями сертифікації. Доведено перспективність FSC сертифікації для вітчизняних лісових господарств. Визначено та аргументовано, що лісова сертифікація є інструментом підвищення конкурентоспроможності вітчизняних лісових господарств та інтеграції на зовнішні ринки.

Ключові слова: лісова сертифікація, FSC сертифікація, лісове господарство, лісистість території, лісова рослинність.

\section{INTRODUCTION}

Forestry belongs to the economic sectors that are of vital importance to the national

(C) O. Tertychna, G. Ryabukha, N. Miroshnyk, K. Kudriashova, 2021 economy, as it relates to all of the processes concerning the reproduction and use of strategic resources - forests. It's difficult to overestimate the importance of forest management for recreation, human health, and 
maintenance of the natural balance, so the problem of forestry development is gradually becoming a priority issue in Ukraine. Forest preservation is one of the most important global issues. Forests play an important role both in forming the carbon balance of the atmosphere and in preserving biodiversity. It's a generally accepted fact that forests and forestry are important today, and there is no doubt about it. A necessary prerequisite for developing sustainable forest management is a system of regular observations, assessment, and analysis of information on the state of forests and forecasting changes in order to provide information and analytical support for decision-making. Such studies are of important environmental, ecologic, and economic importance.

Sustainable management of forest resources in terms of environmental challenges requires regular, objective and timely information on their condition and forecast of their further development. By means of forest certification required information is obtained.

\section{ANALYSIS OF RECENT RESEARCH}

Since the 1990s, there has been a growing worldwide demand for certified forestry products as a result of the impact of non-governmental organizations on nature conservation. As the selling price of certified forest products is $7-10 \%$ higher than in the markets, certification becomes an important argument for product access to «environmentally sensitive markets». This is facilitated by the growth of the area of certified forests, which already is 124 million hectares in all countries of the world [1]. For Ukraine, forest certification can be a tool to increase the competitiveness of domestic timber, timber products, and other forest resources and services in the foreign market. In addition, forest certification contributes to attracting investment to Ukraine, the environmentally safe use of forest resources, and the improvement of forest industry and state's international image, which is necessary for Ukraine's integration into the international forest market.

The purpose of the study is to assess the current state and prospects of forestry in Chernihiv region according to FSC certification.

\section{MATERIALS AND METHODS OF RESEARCH}

The official reporting of certified forestry in Chernihiv region constitutes the materials of this article. General scientific research methods were used for the analysis, including information and bibliographic, analytical generalization of results, and statistical (assessment of the probability of the obtained results, determination of correlations).

\section{RESULTS AND DISCUSSION}

The total area of land plots covered with forest vegetation is 9.6 million hectares, and the forest cover of Ukraine is $15.9 \%$. Nevertheless, despite a rather small forest cover in its territory, Ukraine is 9th place in Europe in terms of forest area and 6th in terms of timber reserves (Fig. 1). Conditions for afforestation in Ukraine are heterogeneous, so forests are distributed unevenly throughout the country [2].

Forest cover in different natural areas has significant differences and does not reach the optimal level at which forests have the most positive effect on climate, soils, water resources, counteract erosion processes, as well as provide more wood. The largest forest cover is typical for the Carpathian zone and is $42 \%$, followed by Polissya forest cover $-26.8 \%$, Forest-steppe $-13 \%$, Steppe $-5.3 \%$. The actual average forest cover of the territory of Ukraine is $15.9 \%$, and the optimal percentage is $20 \%$, which indicates insufficient afforestation of the country [2].

The age structure is dominated by medieval planted vegetation, where the share of mature and overripe plantations is $18.7 \%$. The average age of forests is over 60 years, there is a gradual aging of forests, which leads to the deterioration of their sanitary condition. Ukraine's forests are formed by more than 30 kinds of wood species, among which dominate pine, oak, beech, spruce, birch, alder, ash, hornbeam, and fir [8]. Coniferous planted vegetation occupies $43 \%$ of the total 


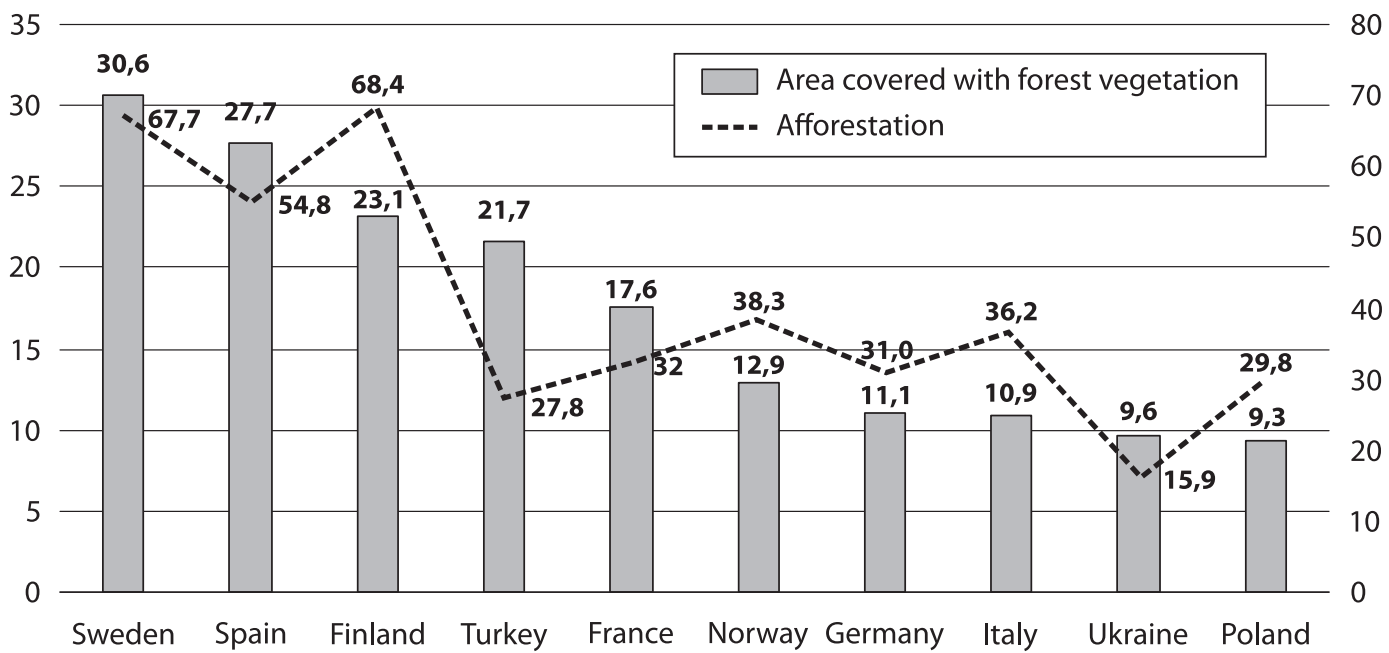

Fig. 1. Afforestation indicators of European countries

area, in particular, pine at 35\%. Hardwood plantations make up $43 \%$, in particular, oak and beech $-37 \%$ [2].

Forest certification is an assessment of compliance of the forestry system with the established international requirements for forest management and forest use on the basis of sustainable development [3]. The purpose of forest certification is to ensure economically, ecologically and socially balanced forest management by complying with relevant generally accepted and credible standards. Environmentally responsible forest management ensures that the harvesting of timber and non-timber forest products does not endanger biodiversity, does not reduce productivity and supports the performance of environmental functions [3]. Socially useful forestry helps both the local population and employees, and society as a whole to reap longterm benefits, and creates powerful incentives for local people to conserve and manage forest resources through long-term plans. Economically viable forestry means that forest use provides sufficient economic benefits without the irreversible loss of forest resources, deteriorating ecosystem quality, and harm to local communities. Contradictions between the need to make a profit and the impact on the forest can be minimized by selling the full range of forest ecosystem products and services at the best cost [1].

Forest certification standards for national, regional and local levels have been developed in Ukraine under two schemes - PEFC (Programme for the Endorsement of Forest Certification) and FSC (Forest Stewardship council) scheme. FSC certification has been investigated in the article based on dissemination rates in Ukraine. The purpose of forest certification is to achieve and maintain a level of forest exploitation, based on economically and environmentally balanced forest management on the relevant international requirements (standards) basis.

The requirements for forest management are based on the norms of the Forest Code of Ukraine, the laws of Ukraine «On Environmental Protection», «On Nature Reserves», «On ecological network of Ukraine» etc., international conventions and agreements, regulations of Ukraine on forestry and environmental protection, international, national, regional and other standards, the international forest certification scheme Forest Stewardship Council (FSC).

The main task of forest certification is organization of forestry in accordance with international requirements on the sustainable development basis. This goal provides in- 
crease the competitiveness of forest products, its promotion in foreign and domestic markets; awareness a wide range of stakeholders about the level of economically, ecologically and socially balanced forestry; elimination trade barriers for forest products [1]. Another important task of forest resources' prevention from depletion is the improvement of technological, technical, organizational and management solutions aimed to increase the productive and reproductive capacity of forests and preserve the biological diversity.

The supervisory audit on forest certification is based on the results of forestry monitoring. Monitoring indicators are established and cover economic and environmental aspects: preservation of production volumes, profitability, volumes and stability of forest use; identification and protection of rare and endangered species, maintenance of forest protection functions, restoration of forest areas after felling. The most detailed monitoring of plantation composition, age distribution, completeness, stock and other indicators, as well as the level of biodiversity, including the availability of vegetation and non-timber products is carried out during the basic forest management, which is carried out as part of the planning process. According to the scale and intensity of forest management measures, the condition of the forest, the volume of forest management products, the chain from the harvester to the consumer, and forest management measures ought to be monitored [4].

The need for forest monitoring is conditioned by the needs of Ukraine's fulfillment of a number of its international obligations, in particular, such as: The UN Convention on Large-Scale Transboundary Air Pollution, the UN Convention on Biological Diversity, and the UN Framework Convention on Climate Change. The monitoring of forests in Ukraine is carried out in accordance with the requirements of the International Joint Program for the Assessment and Monitoring of the Impact of Air Pollution on Forests in the Region of the United Nations Economic Commission for Europe (UNECE ICP Forests). EU legislation defines the UNECE ICP Forests prog- ram as the main forest monitoring program, which covers all countries in the region of the United Nations Economic Commission for Europe (UNECE).

UNECE ICP Forests monitoring activities are carried out at two levels - level I (largescale monitoring), which provides systematic collection of information on changes in the state of forests in time and space, and level II (intensive monitoring), which provides for indepth study of the effects of stress factors on the state of forest ecosystems. In Ukraine, information on the condition of forests in level I monitoring areas is collected on the basis of visual assessments of the condition of tree crowns and visible damage to forest vegetation. The focus of forest vegetation monitoring is the condition of the tree crown, which serves as an indicator that characterizes the general condition of an individual tree or forest. Among the indicators of the condition of the head, which are determined during forest monitoring, the most important is defoliation - a value that indicates a general lack of leaves in the head of the tree. Defoliation is a generalizing indicator of the condition of trees, it characterizes the degree of their damage due to the integral influence of various factors. Defoliation is a pan-European index (indicator) of sustainable forest management, which characterizes the state and viability of forest ecosystems.

The FSC has three types of certification: forestry systems, supply chain, and controlled timber. Different types of certificates relate to different stages of production and further processing of forest products. Compliance with all FSC requirements ensures that FSClabeled materials and products come from responsibly managed forests [5].

Forest Management certification (FM). This is a type of certification for organizations that own or manage forests and want their forest management system to meet the requirements of FSC principles and criteria, which reflect the rules of environmentally responsible, socially profitable, and economically viable forestry. Forest Management certification is granted for forestry enterprises of various forms of ownership and depart- 
mental subordinations that seek to confirm that their forest management system meets the international requirements set out in the form of a standard. The enterprise can obtain two types of certificates: the FM certificate or a «combined» FM/CoC certificate. The $\mathrm{FM} / \mathrm{CoC}$ certificate covers the internal supply chain and allows for the sale of round timber and non-timber products from FSCcertified sites with the «FSC 100\%» statement [5].

Chain of Custody ( $\mathrm{CoC})$ certification is required for producers, processors, and sellers to confirm that the products sold with the FSC statement originate from properly managed forests, controlled sources, recycled materials, or mixtures of the raw materials specified above. At each stage of the production chain, from the place of preparation for the consumer (acceptance, drying, storage, transportation, primary and secondary processing, etc.), FSC certified and acceptable raw materials are used. A CoC certificate is used to sell products with a FSC statement along the supply chain. It can be supplemented with a certificate of controlled wood CW. The certificate should be received by the enterprise that receives raw materials and claims ownership over them at any stage of processing [5].

Controlled Wood (CW). Certified producers often lack certified raw materials or products, while it's impractical to stop the production or reducing its volumes from an economic point of view. In such cases, FSC allows the use of so-called FSC controlled wood [5].

Enterprises are not involved in the preparation of timber, which belongs to the categories unacceptable from the FSC's point of view, and do not mix certified products with those obtained from sources unacceptable to FSC. It is used for forestry enterprises that seek to ensure a responsible forestry system, but cannot yet obtain an FM certificate and wish to avoid the inclusion into unacceptable categories of timber, dealing with producing and selling FSC controlled timber, and/or FSC Mix products. A forestry enterprise can obtain a CW/FM certificate, and another certificate (such as a wood processing certificate) extends the scope of the CoC certificate through an additional $\mathrm{CW}$ certificate. The certificate of controlled timber CW is meant for the enterprises that want to exclude timber of unacceptable categories [5] from the procurement system.

There are three types of certification: individual, group, and multi-location. Individual certification is used for one legal entity. Group certification is used for several legal entities (group of small businesses) who want to reduce the cost of certification [5]. The group is then united under a single certificate, and group members share the costs. The main responsibility lies with the manager elected by all members, who is responsible for ensuring that all members of the group meet the requirements of the FSC and interacting with the certification authority. Audits among team members are conducted selectively. However, if any member of the group does not meet the requirements of the $\mathrm{FSC}$, the certificate is either not issued or suspended.

Multi-location certification is designed for large businesses that have two or more physical locations. This is more cost-effective than certifying each location individually. However, if any physical location does not meet the requirements of the $\mathrm{FSC}$, the certificate is either not issued or suspended [5].

According to data from 2017, Ukraine is a leading nation among European countries in terms of its area of certified forests ( $5^{\text {th }}$ place), the growth rate of the area ( $3^{\text {rd }}$ place), the growth rate of the number of forestry certificates ( $2^{\text {nd }}$ place), and the growth rate of supply chain certificates $\left(5^{\text {th }}\right.$ place). During the year, the area of certified forests increased to 3.917 million hectares (an increase by $27 \%$ ), and the number of supply chain certificates increased to 212 (an increase by 30\%). These are quite impressive results, as the average European rate is 2 and 6 percent of growth in forest area and the number of supply chain certificates, respectively $[4 ; 6]$

According to the Forest Stewardship Council (FSC), an international non-profit non-governmental organization, 4.36 million hectares of forests or $42 \%$ of the country's 
forest areas were certified in Ukraine [4] as of January 1, 2020.

After analyzing the data from 01.06.2020 of certified forest areas by region, we can determine that the largest of them include: Zhytomyr region -797 thousand hectares, Lviv region -478 thousand hectares, Volyn 475 thousand hectares, Transcarpathia -447 thousand hectares, Rivne region -444 thousand hectares, Chernihiv region -400 thousand hectares [2].

Thus, we can conclude that the forestry in Chernihiv region is set on increasing the area of certified forest areas. As of June 20, 2020, there are three operating certified state-owned enterprises in Chernihiv region: Novhorod-Siversky forestry, Nizhyn forestry, and Kholmy forestry.

The state enterprise «Novgorod-Siversky forestry» is located in the north-eastern part of Chernihiv region, the enterprise includes 7 forestries. The total area of the enterprise is 30407 hectares, including area covered with forest vegetation -27427.5 hectares. The total certified area is 30407 hectares [8]. «Novhorod-Siversky forestry»

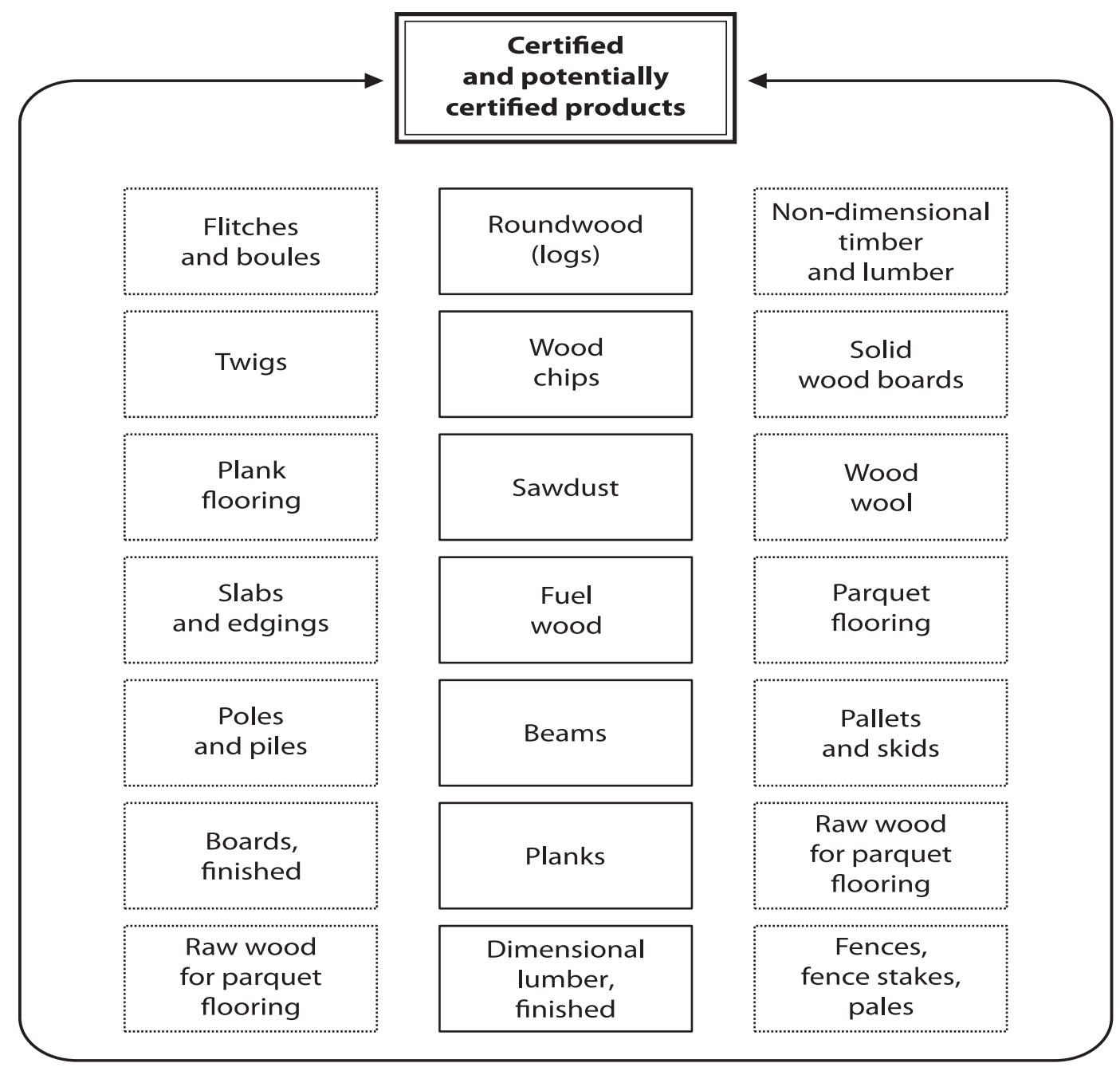

Fig. 2. Certified and potentially certified products of the forestries in Chernihiv region 
is certified for such types of wood species as Acer platanoides; Alnus glutinosa; Betula pendula; Picea abies; Pinus sylvestris; Populus spp.; Populus tremula; Quercus robur; Tilia cordata Mill. $=$ Winterlinde $($ Syn.: $T$. parvifolia) [8].

The state enterprise «Nizhyn forestry» is located in the central part of Chernihiv region, the enterprise consists of 8 forestries. The total area of the enterprise is $\mathbf{4 7 6 1 4 . 4}$ hectares, including area covered with forest vegetation -42252.7 hectares. The total certified area is 47614.4 hectares [10]. $\ll \mathrm{Ni}$ zhyn forestry» is certified for such types of wood species as Acer platanoides; Alnus glutinosa; Betula pendula; Carpinus betulus L.; Fraxinus excelsior, Picea abies; Pinus sylvestris; Populus nigra; Populus tremula; Quercus robur, Quercus rubra; Quercus spp.; Robinia pseudoacacia L.; Tilia cordata P. Mill.; Ulmus spp. [9].

The state enterprise «Kholmy forestry» is located in the northern part of Chernihiv region, the enterprise consists of 6 forestries. The total area of the enterprise is 38866.4 hectares, the total certified area is 38866.4 hectares [10]. «Kholmy Forestry» is certified for such types of wood species as Acer platanoides; Alnus glutinosa; Betula pendula; Carpinus betulus L.; Fraxinus excelsior, Picea abies; Pinus sylvestris; Populus nigra; Populus tremula; Quercus robur; Robinia pseudoacacia L.; Salix fragilis L.; Tilia cordata P. Mill.; Ulmus spp. [10]. The already certified and potentially certified products of Novhorod-
Siversky forestry, Nizhyn forestry, and Kholmy forestry in 2015-2020 have been identified in accordance with official reports of the enterprises (Fig. 2).

After analyzing forestry activity in Chernihiv region, we can identify the current challenges for their improvement: ensuring ecologically oriented forest management and integrated use of forest resources, reducing the volume of continuous forest cleaning by instead utilizing gradual and selective cleaning, ensuring the preservation of forest biological diversity, the inventory and optimization of the forest nature reserves network, study of new technologies and methods of forestry organization and management, and expansion of cooperation between scientific and educational organizations.

\section{CONCLUSIONS}

Thus, forestry of Chernihiv region is an important component of the economy, because, in addition to providing raw materials for many industries, it is also the basis for economic activities that involve job creation and product manufacturing. Forestry is important for the sustainable development of the agroindustrial complex, as well as for the region's security. An effective and flexible process of reorientation of forest resources management from the classical economic principles to ecological and economic ones is forest certification, which covers all types of activities in management, forest use, and reforestation.

\section{ЛІТЕРАТУРА}

1. Рекомендації щодо організації та проведення лісової сертифікації в Україні за схемою FSC / Робоча група з розробки національних стандартів лісової сертифікації для України. Київ, 2017. 8 с. URL: https://ua.fsc.org/preview.fsc.a-216.pdf (дата звернення: 05.07.2020).

2. Публічний звіт Державного агентства лісових ресурсів України за 2019 рік. Київ, 2020. 43 с. URL: https://menr.gov.ua/files/images/news 2020 (дата звернення: 05.07.2020).

3. Сертифікація лісів / Чернігівське обласне управління лісового та мисливського господарства. URL: https://chernigivlis.gov.ua/\%D0\%B1\%D0\% B5\% D0\%B7-8/sertifikaciya-lisiv (дата звернення: 20.07.2020).
4. FSC в Україні / Forest Stewardship Council. URL: https://ua.fsc.org/ua-ua/pro-nas/fsc (дата звернення: 01.07.2020).

5. Отримати сертифікат FSC / Forest Stewardship Council. URL: https://ua.fsc.org/ua-ua/_certification/fsc-02 (дата звернення: 01.07.2020).

6. Факти та цифри / Forest Stewardship Council. URL: https://ua.fsc.org/ua-ua/nasha-diyalnist/ facts and figures (дата звернення: 01.07.2020).

7. Сертифікація лісів / Державне агентство лісових ресурсів. URL: http://dklg.kmu.gov.ua/forest/control/uk/publish/article;jsessionid=9D4 B7A7DF02206520D00EE03B9CD5290.app1? art_id=138413\&cat_id=36096 (дата звернення: 20.07.2020). 
8. Сертифікаційний Звіт про 4-й щорічний аудит Державного підприємства «Новгород-Сіверське лісове господарство» в Чернігівській області / FSC Лісоуправління. 2019. URL: http://fsc.force. $\mathrm{com} /$ servlet/servlet. FileDownload?file $=00 \mathrm{Pf} 3000$ 00wGSfTEAW (дата звернення: 10.07.2020).

9. Сертифікаційний Звіт про 4-й щорічний аудит Державного підприємства «Ніжинське лісове господарство» в Чернігівській області / FSC Лісо- управління. 2019. URL: http://fsc.force.com/ servlet/servlet. FileDownload?file $=00 \mathrm{Pf} 300000 \mathrm{zb}$ KmGEAU (дата звернення: 10.07.2020).

10. Сертифікаційний звіт про 4-й щорічний аудит Державного підприємства «Холминське лісове господарство» в Чернігівській області / FSC Лісоуправління. 2019. URL: http://fsc.force.com/ servlet/servlet.FileDownload?file $=00 \mathrm{Pf} 300000$ wGX6iEAG (дата звернення: 10.07.2020).

\section{REFERENCES}

1. Robocha hrupa z rozrobky natsionalnykh standartiv lisovoi sertyfikatsii dlia Ukrainy [Working Group on the Development of National Forest Certification Standards for Ukraine]. (2017). Rekomendatsii shchodo orhanizatsii ta provedennia lisovoi sertyfikatsii v Ukraini za skhemoiu FSC [Recommendations for the organization and conduct of forest certification in Ukraine under the FSC]. Kyiv. URL: https:// ua.fsc.org/preview.fsc.a-216.pdf [in Ukrainian].

2. Publichnyi zoit Derzhavnoho ahentstva lisozykh resursiv Ukrainy za 2019 rik [Public report of the State Agency of Forest Resources of Ukraine for 2019]. (2019). URL: https://menr.gov.ua/files/images/ news_2020/26022020.pdf [in Ukrainian].

3. Chernihivske oblasne upravlinnia lisovoho ta myslyvskoho hospodarstva [Chernihiv Regional Department of Forestry and Hunting]. (n.d.). Sertyfikatsiia lisiv [Forest certification]. URL: https://chernigivlis.gov. ua/\%D0\%B1\%D0\%B5\%D0\%B7-8/sertifikaciyalisiv [in Ukrainian].

4. Forest Stewardship Council (n.d.). FSC v Ukraini [FSC in Ukraine]. URL: https://ua.fsc.org/ua-ua/ pro-nas/fsc [in Ukrainian].

5. Forest Stewardship Council (n.d.). Otrymaty sertyfikat FSC [Get a FSC certificate]. URL: https:// ua.fsc.org/ua-ua/_certification/fsc-02 [in Ukrainian].

6. Forest Stewardship Council (n.d.). Fakty ta tsyfry [Facts and figures]. URL: https://ua.fsc.org/ua-ua/ nasha-diyalnist/facts_and_figures [in Ukrainian].
7. Derzhavne ahentstvo lisovykh resursiv Ukrainy [State Agency of Forest Resources of Ukraine]. (n.d.). Sertyfikatsiia lisiv [Forest certification]. URL: http://dklg.kmu.gov.ua/forest/control/uk/publish/ article;jsessionid=9D4B7A7DF02206520D00EE03 B9CD5290.app1?art_id=138413\&cat_id=36096 [in Ukrainian].

8. Sertyfikatsiinyi zoit pro 4-y shchorichnyi audyt Derzhavnoho pidpryiemstva «Novhorod-Siverske lisove hospodarstvo»v Chernihivskii oblasti [Certification report on the 4th annual audit of the State Enterprise «Novgorod-Siversky Forestry» in the Chernihiv region]. (2019). URL: http://fsc.force.com/servlet/ servlet. FileDownload?file $=00 \mathrm{Pf} 300000 \mathrm{wGSf}$ TEAW [in Ukrainian].

9. Sertyfikatsiinyi zvit pro 4-y shchorichnyi audyt Derzhavnoho pidpryiemstva «Nizhynske lisove hospodarstvo»v Chernihivskii oblasti [Certification report on the $4^{\text {th }}$ annual audit of the State Enterprise «Nizhyn Forestry» in Chernihiv region]. (2019). URL: http://fsc. force.com/servlet/servlet.FileDownload?file= 00Pf300000zb KmGEAU [in Ukrainian].

10. Sertyfikatsiinyi zoit pro 4-y shchorichnyi audyt Derzhavnoho pidpryiemstva «Kholmynske lisove hospodarstvo»v Chernihivskii oblasti [Certification report on the 4th annual audit of the State Enterprise «Kholmy Forestry» in Chernihiv region]. (2019).URL: http://fsc.force.com/servlet/servlet. FileDownload?file=00Pf300000 wGX6iEAG [in Ukrainian].

Стаття надійшла до редакції журналу 23.01.2021 